\title{
IMP の構造を用いた位相補償ロバスト制御
}

\author{
王荵*・渡 部 慶 二*・村 松 鋭 一* \\ 有我祐一*・遠藤茂*
}

Phase-Compensated Robust Control on the basis of IMP

Rui Wang*, Keiji Watanabe*, Eiichi Muramatsu*, Yuichi Ariga*' and Sigeru Endo*

This paper presents a new concept of the robust control, which is named by phase-compensated robust control. The mechanism of robust stability is analyzed by internal model parametrization (IMP). To overcome the conservativeness of the traditional methods based on the small gain theorem, the phase compensation is introduced. The robust stability condition is derived for the new control scheme. The simple design method is proposed.

Key Words : robust control, phase compensation, internal model parametrization

\section{1. はじめに}

ロバスト制御系の設計は, 制御対象 $G(s)(1+\Delta(s))$ のデ ル誤差 $\Delta(s)$ を評価関数で見積もり, 評価関数と相補感度の 積が 1 を超えないように設計してきた1). しかし，この方法 には，いくつかの問題がある.

（1）スモールゲイン定理を基にしているため保守性が高 い.

（2）モデル誤差の情報は，拘束条件にしか使われていな u.

（3）トレードオフの関係にある複数の仕様を重み関数と して与え，一般化プラントにまとめ解を求めてい る. 解が得られるまでに重み関数の調整に多くの時 間を要することがある。

（4）モデル誤差を厳密に見積もると, 安定仕様が満たさ れても，応答が振動的になることがある。

これらの問題は, 安定性に関係するゲインと位相の 2 つの うち，ゲインだけを用いているからと考えられる．著者の一 人は，位相も考慮した内部モデル制御2)のロバスト安定性に ついて検討し, 低感度でロバスト安定を得るための必要十分 条件は, 制御対象とモデルの相対次数が一致していることを 示し ${ }^{3)}$ ，相対次数を一致させるための方法を提案した4). 内 部モデル制御は内部モデルパラメトリゼーションを介し, 通 常のフィードバック系に帰着できるので2), 上記の結果は, 一般のフィードバック制御系にあてはまる。山田は, 上記を

\footnotetext{
* 山形大学工学部応用生命システム工学科 米沢市城南 4-3-16

* Yamagata University, 4-3-16 Jonan, Yonezawa

(Received June 3, 2005)

(Revised October 14, 2005)
}

別の角度から検討し5)，モデルの相対次数の方が高い場合ま で拡張できることを示しだ!. ししし，実際の制御対象の相 対次数を正確に把握することが困難な場合や，むだ時間があ る場合は，上記の理論が適用できない.

本稿は, これらの問題を根本的に解決するため, 内部モデ ル・パラメトリゼーション(IMP)のロバスト制御構造を利 用し, モデル誤差の位相情報を安定性, 応答特性の改善に使 う新しいロバスト制御方法を提案する。

はじめに, 内部モデル・パラメトリゼーション(IMP)を もとに従来のロバスト制御を解析し, 保守性の原因を解明す る.つぎに, 保守性を解消するため, IMP のロバスト制御 構造を利用し, 位相補償を行なうロバスト制御法を提案す る.さらに，提案方法のロバスト安定条件を導きだし，それ をもとにした設計法を提案する. 最後に, 本稿の有効性を, $H^{\infty}$ 制御と比較しながら示す. 本法の特徵は下記の通りであ る.

（1）モデル誤差の位相情報を, 制御対象のステップ応答 の時間遅れから求めるので, 化学プラントのような 応答の遅い系にも適用可能である.

（2）モデル誤差の位相情報を安定性の改善に用いるの で，保守性の少ないロバスト安定条件が得られる。

（3）特に安定な制御対象に対しては，位相補償するだけ で，後は，モデル誤差に依存しないエラー・フリー 設計ができる。

（4）モデル誤差の位相情報が，あらかじめ，感度と相補 感度関数の中に組み込まれているので, トレードオ フが解消される。

（5）モデル誤差の位相情報を安定性, 応答の改善に用い ており, 従来のロバスト制御系設計よりも, 安定 性, 応答特性が優れた制御系が構成可能である. 


\section{2. 内部モデル・パラメトリゼーション}

Fig. 1 に示す 1 入力 1 出力制御系を考える.ただし, $G(s)(1+\Delta(s))$ は制御対象である. $G(s)$ はモデルで, 1 $+\Delta(s)$ はモデル誤差で, $G(s)(1+\Delta(s))$ の不安定極数は, $G(s)$ と同じとする， $r$ は目標入力, $u, y$ は入出力, $d$ は外 乱で, $G_{c}(s)$ は制御器である.

すべての制御器 $G_{c}(s)$ は,

$$
G_{c}(s)=\frac{P(s)}{1-G(s) P(s)}
$$

と内部モデル・パラメトリゼーション表示(IMP)すること ができる2).ただし， $P(s)$ は自由パラメータである.

(1)式を用いると，モデル誤差が $\Delta(s)=0$ のとき， $r, d$ から $y, u$ までの伝達特性は次式で与えられる。

$$
\left[\begin{array}{l}
y(s) \\
u(s)
\end{array}\right]=\left[\begin{array}{cc}
G(s) P(s) & (1-G(s) P(s)) G(s) \\
P(s) & -P(s) G(s)
\end{array}\right]\left[\begin{array}{c}
r(s) \\
d(s)
\end{array}\right]
$$

フィードバック系が内部安定のための必要十分条件は, $P(s), G(s) P(s)$, および $(1-G(s) P(s)) G(s)$ がすべて安定 なことである ${ }^{2)}$. 出力側感度関数は,

$$
S(s)=1-G(s) P(s)
$$

で, 相補感度関数は

$$
T(s)=G(s) P(s)
$$

で与えられる。

\section{3. スモールゲイン定理に基づくロバスト安定化}

モデル誤差が $\Delta(s) \neq 0$ のとき， (2) 式は

$$
\begin{aligned}
& {\left[\begin{array}{l}
y(s) \\
u(s)
\end{array}\right]=\frac{1}{1+G(s) P(s)\{1+\Delta(s)-1)\}}} \\
& {\left[\begin{array}{cc}
G(s) P(s)(1+\Delta(s)) & (1-G(s) P(s)) G(s)(1+\Delta(s)) \\
P(s) & -P(s) G(s)(1+\Delta(s))
\end{array}\right]\left[\begin{array}{c}
r(s) \\
d(s)
\end{array}\right]}
\end{aligned}
$$

となる.内部安定であるための必要十分条件は，(5)式右辺 の行列の要素が安定なことである，P(s), $G(s) P(s)$ ，およ び $(1-G(s) P(s)) G(s)$ が安定とすると，(5) 式が内部安定 であるための必要十分条件は,

$$
\bar{G}(s)=\frac{1}{1+G(s) P(s)\{1+\Delta(s)-1)\}}
$$

がロバスト安定なことである。（6) 式が，ロバスト安定であ るための必要十分条件は, $G(s) P(s)\{1+\Delta(s)-1\}$ のベクト ル軌跡が $(-1,0)$ 点の右側を通ることである.

ここで，ロバスト安定性に影響するモデル誤差が， $\{1+\Delta(s)-1\}$ のように, $1+\Delta(s)$ と 1 の差になっているのが 内部モデル・パラメトリゼーション独自の構造である。これ

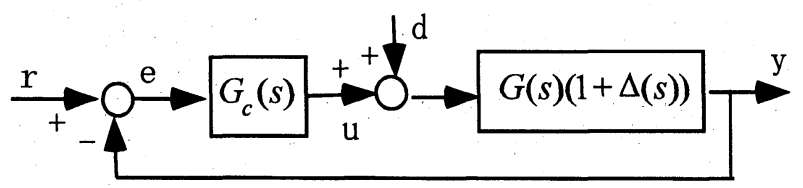

Fig. 1 Feedback control system
に対し，従来のスモールゲイン定理に基づくロバスト制御 は，1の部分を消去した

$$
G(s) P(s)\{1+\Delta(s)-1\}=G(s) P(s) \Delta(s)
$$

をもとに設計を行なっている。モデル詋差を

$$
|\Delta(j \omega)|<\left|W_{T}(j \omega)\right|, \quad \forall \omega \geq 0
$$

で見積もる. $|\Delta(j \omega)|$ は直接測定できないので，

$$
\frac{\left\|G_{p}(j \omega)|-| G(j \omega)\right\|}{|G(j \omega)|} \leq|\Delta(j \omega)| \leq \frac{\left|G_{p}(j \omega)\right|+|G(j \omega)|}{|G(j \omega)|}
$$

の関係から，低域では左辺で，高域では右辺で，（8)式を満 たす重み関数 $W_{T}(s)$ を求める。（7 ) 式を満たす任意のモデ ル誤差に対し制御系が安定であるために必要十分条件は

$$
|T(j \omega)|<\frac{1}{\left|W_{T}(j \omega)\right|}, \forall \omega \geq 0
$$

を満たすことである，目標追従特性，外乱抑制特性をよくす るには，適当な $W_{s}(s)$ を選び

$$
|S(j \omega)|<\frac{1}{\left|W_{s}(j \omega)\right|}, \forall \omega \geq 0
$$

を満たすように設計する。感度を 0 ，相補感度を 1 にできる のは， $|\Delta(j \omega)|$ が 1 を超えない範囲に限られる.

しかし, Fig. 2 からわかるように， $|1+\Delta(j \omega)| \leq 1$ であっ

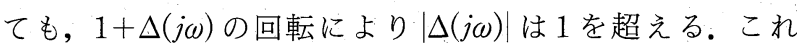
が，保守性を高くする原因になっている．また，（7)式の左 辺と右辺の差が小さいと，モデル誤差時の開ループダインの 位相余裕が小さく，混合感度仕様を満たしても，制御系の応 答が振動的になる場合がある。

\section{4. 位相補 償}

上記の問題は, Fig. 2 のベクトル 1 が固定されているから である.この問題を解決するには, $\{(1+\Delta(j \omega))-1\}$ のべク トル 1 を，モデル誤差 $1+\Delta(j \omega)$ を追従できる $M(j \omega)$ に代 え, $1+\Delta(j \omega)$ と $M(j \omega)$ の差 $\{1+\Delta(j \omega)-M(j \omega)\}$ にすること である.そうすればFig. 3 に示すように，安定性や応答に 影響する正味の誤差の絶対值を小さくしたり，位相を進ませ ることができる ${ }^{8), 91 .}$

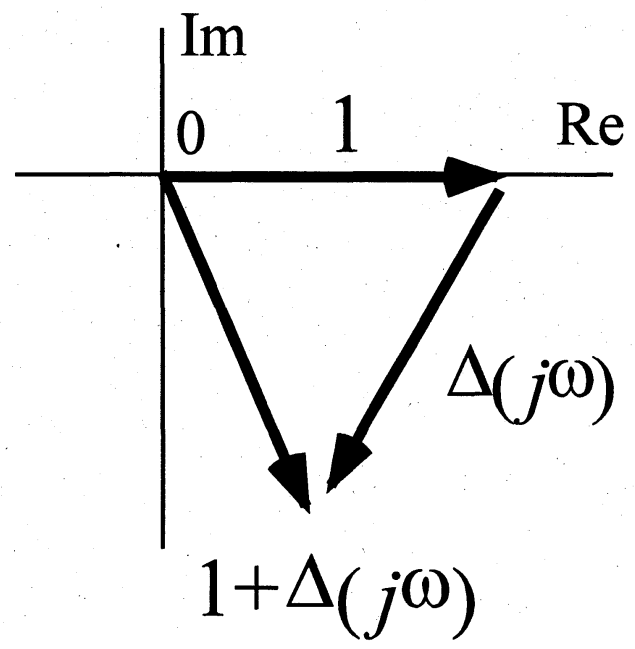

Fig. 2 Relation between $1+\Delta(j \omega)$ and 1 


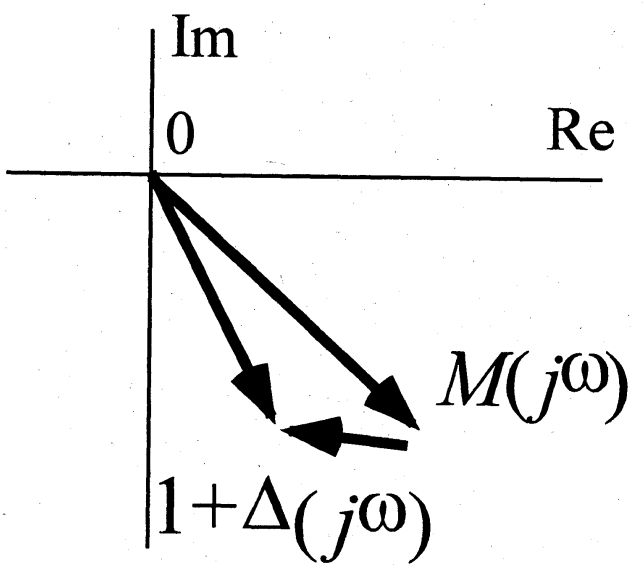

Fig. 3 Replacement of the vector 1 by $M(s)$

$\{1+\Delta(s)-1\}$ を, $\{1+\Delta(s)-M(s)\}$ にするとは, IMP 表示の制御器 ( 1 ) 式を

$$
G_{c}(s)=\frac{P(s)}{1-G(s) P(s) M(s)}
$$

に変えることである.

$$
1+\Delta(s)=M(s) \text { とすると }
$$

$$
\left[\begin{array}{l}
y(s) \\
u(s)
\end{array}\right]=\left[\begin{array}{cc}
G(s) P(s) M(s) & (1-G(s) P(s) M(s)) G(s) M(s) \\
P(s) & -P(s) G(s) M(s)
\end{array}\right]\left[\begin{array}{c}
r(s) \\
d(s)
\end{array}\right]
$$

が成り立つ.フィードバック系が内部安定のための必要十分 条件は, $P(s), G(s) P(s) M(s)$ およ゙ $(1-G(s) P(s) M(s))$ $G(s) M(s)$ がすべて安定なことである. 出力側感度は

$$
S(s)=1-G(s) P(s) M(s)
$$

であり, 相補感度は

$$
T(s)=G(s) P(s) M(s)
$$

であり，モデル誤差の情報を含んだ形となる。

$$
1+\Delta(s) \neq M(s) \text { のとき，(12) 式は }
$$

$$
\begin{aligned}
& {\left[\begin{array}{l}
y(s) \\
u(s)
\end{array}\right]=\frac{1}{1+G(s) P(s)\{1+\Delta(s)-M(s)\}}} \\
& {\left[\begin{array}{c}
G(s) P(s)(1+\Delta(s))(1-G(s) P(s) M(s)) G(s)(1+\Delta(s)) \\
P(s) \\
-P(s) G(s)(1+\Delta(s))
\end{array}\right]\left[\begin{array}{l}
r(s) \\
d(s)
\end{array}\right]}
\end{aligned}
$$

となる。（12)式の内部安定のもとで，(15)式が内部安定であ るための必要十分条件は,

$$
\widetilde{G}(s)=\frac{1}{1+G(s) P(s)\{1+\Delta(s)-M(s)\}}
$$

がロバスト安定なことである. モデル誤差の項は， $\{1+\Delta(s)$ $-1\}$ から $\{1+\Delta(s)-M(s)\}$ に代わっていることがわかる.

（16）式のロバスト安定性を包・荒木の方法7) を応用して考 える。（16)式の特性方程式は

$$
1+G(s) P(s)\{1+\Delta(s)-M(s))=1+T(s) Q(s)=0
$$

である。ただし， $T(s)$ は (14)式で与えられ

$$
Q(s)=(1+\Delta(s)) M^{-1}(s)-1
$$

である。（17)式は

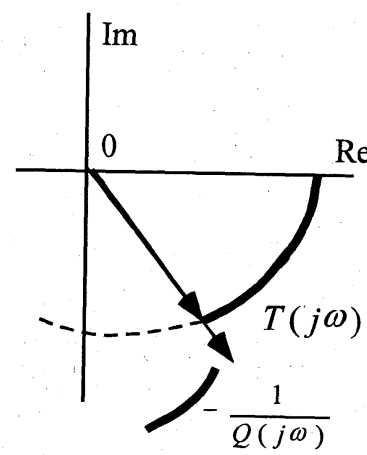

(a) stable

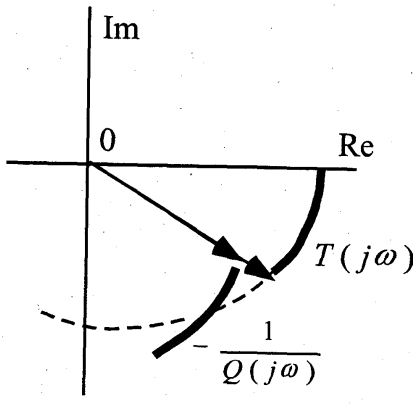

(b) unstable
Fig. 4 Stability criterion

$$
T(s)=-\frac{1}{Q(s)}
$$

となる。

〈定理 1〉 (12) 式は，内部安定とする. $1+\Delta(s) \neq M(s)$ の とき, Fig. 4(a) に示すように, すべての $\omega \geq 0$ で, $T(j \omega)$ のベクトルが, $-1 / Q(j \omega)$ のベクトルの延長上にいかないと き，そのときに限って，(16)式は安定である.

（証明） 開ループ伝達関数 $T(j \omega) Q(j \omega)$ のベクトル軌跡が 負の実軸を横切るとき，

$$
T(j \omega)=-\frac{\rho}{Q(j \omega)}
$$

が成り立つ.ただし， $T(j \omega) Q(j \omega)$ のベクトル軌跡が点 $(-1,0)$ 上あるいは点の左側を横切るときは $\rho \geq 1$ であり, 点 $(-1,0)$ の右側を横切るときは $\rho<1$ である. 後者の場合, $T(j \omega)$ のベクトルは, $-1 / Q(j \omega)$ のベクトルの延長上にない (証明終).

$-1 / Q(j \omega)$ はモデル誤差 $1+\Delta(j \omega)$ を含むため, 定理 1 を 用いて安定判別することができない．安定判別ができるよう にするには， $-1 / Q(j \omega)$ の存在範囲を特定することが必要で ある，そのため， $-1 / Q(j \omega)$ をつぎのように展開する。

$$
-\frac{1}{Q(j \omega)}=\frac{1}{1-\gamma(\omega) e^{j \theta(\omega)}}=\frac{1-\gamma(\omega) \cos \theta(\omega)+j \gamma(\omega) \sin \theta(\omega)}{1+\gamma(\omega)^{2}-2 \gamma(\omega) \cos \theta(\omega)}
$$

ただし，

$$
\begin{aligned}
& \gamma(\omega)=\left|(1+\Delta(j \omega)) M^{-1}(j \omega)\right| \\
& \theta(\omega)=\angle(1+\Delta(j \omega))-\angle M(j \omega)
\end{aligned}
$$

$-1 / Q(j \omega)$ の存在範囲を調べるために， $\gamma, \theta$ を独立した パラメータとした

$$
H(\gamma, \theta)=\frac{1}{1-\gamma e^{j \theta}}=\frac{1-\gamma \cos \theta+j \gamma \sin \theta}{1+\gamma^{2}-2 \gamma \cos \theta}
$$

を考える. $\theta$ をパラメー夕に, $\gamma$ を 2 から 0 まで変えると Fig. 5 が得られる. 実線が $H(\gamma, \theta)$ で，虚軸に平衡な点線 が，点 $(0.5,0)$ を通る直線である．原点の周りの点線の円 は，単位円である。

Fig. 5 に示されるように, $H(\gamma, \theta)$ は, $\gamma=2$ の点 $(1,0)$ の 近くから始まり, 反時計方向に回りながら, $\gamma=1$ で

$$
H(1, \theta)=\frac{1}{2}+j \frac{1}{2} \cot \left(\frac{\theta}{2}\right)
$$




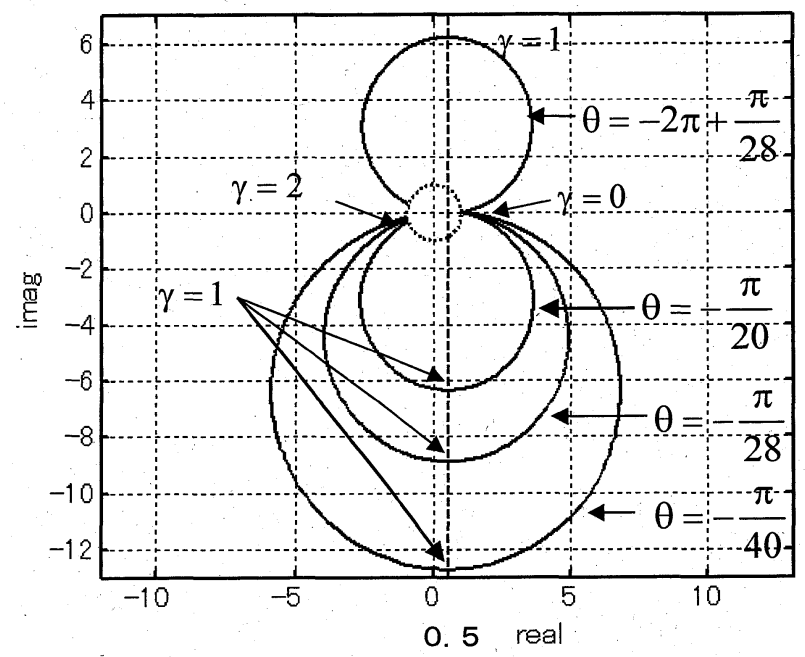

Fig. 5 Characteristic of $H(\gamma, \theta)$

となり, 点 $(0.5,0)$ を通り虚軸に平行な直線上にくる.さら に， $\gamma$ を小くすると右側に回りながら $\gamma=0$ で点 $(-1,0)$ に達する. $\gamma>1$ で $\operatorname{Re}[H(\gamma, \theta)]<0.5$ で, $\gamma<1$ でRe $[H(\gamma$, $\theta)]>0.5$ である.また， $\theta$ が 0 から $-\pi$ に近づくにつれ， $H(\gamma, \theta)$ は内側に縮小し, 一 る.これらのことから，(22)式の $\gamma(\omega)$ が 1 以下であれば, $-1 / Q(j \omega)$ は, 点 $(0.5,0)$ を通り虚軸に平行な直線の右側に 存在する。これより，つぎの定理が得られる。

〈定理 2〉ある $\omega_{c}>0$ があり,$\omega>\omega_{c}$ で

$$
\begin{aligned}
& \operatorname{Re}\left[\frac{1+\Delta(j \omega)}{M(j \omega)}\right]<1 \\
& \operatorname{Re}[T(j \omega)]<0.5
\end{aligned}
$$

とする. $0 \leq \omega \leq \omega_{c}$ で, $T(j \omega)$ のベクトルが, $-1 / Q(j \omega)$ の ベクトルの延長上にいかなければ，(16)式は安定である.

（証明）（26)式から， $\omega>\omega_{c}$ で，

$$
\operatorname{Re}\left[-\frac{1}{Q(j \omega)}\right]>0.5
$$

となる。これと仮定から，すべての周波数にわたり $T(j \omega)$ のベクトルは, $-1 / Q(j \omega)$ のベクトルの延長上にいくことは ない. 定理 1 から，(16)式は安定である(証明終).

定理 2 と Fig. 5 からつぎのことがわかる。(22)，(23)式 で， $\omega$ が 0 から大きくなるに従い， $\gamma(\omega)$ が 1 を超える值か ら 0 に, $\theta(\omega)$ が 0 から $-\pi$ に向かうとする. $-1 / Q(j \omega)$ の ベクトルは, Fig. 5 の左半平面上の点から, 反時計方向に回 転し, 点 $(1,0)$ に近づく. 一方， $\omega$ が大きくなるに従い $T(j \omega)$ の位相は負の方向に増加するとすると, $T(j \omega)$ の心゙ クトルは，実軸から時計方向に回転する。この $T(j \omega)$ の時 計方向の回転と $-1 / Q(j \omega)$ の反時計方向の回転で, $T(j \omega)$ と $-1 / Q(j \omega)$ のベクトルが交差するとき, $T(j \omega)$ のべクト ルが, $-1 / Q(j \omega)$ のべクトルの延長上にいかないようにする にはつぎのことが考えられる。

（注意1）（23）式で，モデル誤差 $1+\Delta(s)$ の位相遅れを $M(s)$ の位相遅れで補償し， $\theta(\omega)$ の值を小さくする。そう.す
れば, $-1 / Q(j \omega)$ のベクトルが長くなり,$T(j \omega)$ のベクトル が $-1 / Q(j \omega)$ のベクトルの延長上にいくことを妨げること ができる。

（注意 2） $\gamma=\left|(1+\Delta(j \omega)) M^{-1}(j \omega)\right|$ が 0 に近づく前に， $M(j \omega)$ の位相遅れを使って $T(j \omega)$ のベクトルを時計方向に 回転させる、そうすれば， $T(j \omega)$ のベクトルが $-1 / Q(j \omega)$ のベクトルの延長上にいくことを妨げることができる.

（注意 $3 ）$ 高い周波数まで $|T(j \omega)| \approx 1$ のままで(27)式を 満たすためには， $M(j \omega)$ の回転を一 $\pi$ 以内で止める必要が ある。

\section{5. 位相を考慮したモデル誤差の評価とロバスト安定条 件}

定理 2 の安定判別が適用できるように $-1 / Q(j \omega)$ の存在 範囲をさらに絞りこむと同時に，注意 1)〜3) を満たす $M(s)$ を特定できるように，モデル誤差につぎの条件を入れる.

〈仮定 1〉（位相条件)

$-\omega L \leq \angle(1+\Delta(j \omega)), \forall \omega \geq 0$

ただし， $L>0$.

〈仮定 2〉（ゲイン条件）

$\left|W_{I}(j \omega)\right| \leq|1+\Delta(j \omega)| \leq 1, \quad \forall \omega \geq 0$ ただし， $\left|W_{I}(j \omega)\right|$ は， $\omega \geq 0$ に関し単調減少関数とする. 制 御対象 $G(s)(1+\Delta(s))$ が安定のときは $\left|W_{I}(j \omega)\right|=0$ とする.

位相条件(29)式をラプラス変換上で考えると, 左辺は $e^{-s L}$ を意味する。したがって，(29)式を満たす $L$ は，モデ ル $G(s)$ に対する制御対象 $G(s)(1+\Delta(s))$ のステップ応答の 立ち上がり部分の時間遅れとして見積もることができる.

これより，注意 1$)$ の $\theta(j \omega)$ への位相補償，注意 2)の $T(j \omega)$ の回転, そして注意 3$)$ の $M(j \omega)$ の回転を $-\pi$ で止め る3つの条件を満たす $M(s)$ として, $e^{-s L}$ の Padéの 1 次近 似

$$
M(s)=\frac{1-\frac{L}{2} s}{1+\frac{L}{2} s}=\frac{2-L s}{2+L s}
$$

が考えられる。

$$
\angle M(j \omega)=-2 \tan ^{-1} \frac{L \omega}{2}
$$

となるので,

$$
\bar{\theta}(\omega)=-\omega L+2 \tan ^{-1} \frac{L \omega}{2}
$$

とおく. 仮定 1 から

$$
\bar{\theta}(\omega) \leq \theta(\omega)
$$

と $\theta(\omega)$ の最大遅れが特定される.

一方，ゲイン条件は

$$
\frac{|G(j \omega)(1+\Delta(j \omega))|}{|G(j \omega)|}
$$

から（８）式より正確に見積もることができる，モデルのゲ インを調整することで，(30)式の上限を満たすことができ る.また，(30)式の下限は，実際には，全周波数にわたり測 
定する必要はなく，ある低周波領域で十分である。すなわ ち，(31)式から $|M(j \omega)|=1$ であり，(30)式から，すべての 周波数で(26)式が成り立つ。さらに，(31)式から

$$
\angle M(j \omega)=-\frac{\pi}{2}
$$

とする角周波数 $\omega=\sqrt{2} / L$ で, $G(j \omega) P(j \omega)$ が大きなゲイン や位相進み特性をもたない限り,

$$
\operatorname{Re}\left[T\left(j \frac{\sqrt{2}}{L}\right)\right]=\operatorname{Re}\left[G\left(j \frac{\sqrt{2}}{L}\right) P\left(j \frac{\sqrt{2}}{L}\right) M\left(j \frac{\sqrt{2}}{L}\right)\right]<0.5
$$

を満たすことができる。これより (26)，（27) 式を満たす $\omega_{c}$ が 0 と $\sqrt{2} / L$ の間に存在する.したがって, $0 \leq \omega \leq \sqrt{2} / L$ の範囲で $(30)$ 式の下限をつかんでいれば，ほぼ十分である.

(33) 式と Fig. 5 の特性から, $0 \leq \omega \leq \omega_{c}$ のすべての -1 / $Q(j \omega)$ は, $H\left(\gamma, \bar{\theta}\left(\omega_{c}\right)\right)\left|W_{I}\left(j \omega_{c}\right)\right| \leq \gamma \leq 1$ の外側にある. $0 \leq$ $\omega \leq \omega_{c}$ の個別の周波数での $-1 / Q(j \omega)$ は, $H(\gamma$, $\bar{\theta}(\omega))\left(\left|W_{I}(j \omega)\right| \leq \gamma \leq 1\right)$ の外側にある.これで, $-1 / Q(j \omega)$ の存在範囲が特定できたので, つぎの定理が成り立つ.

〈定理 3〉仮定 1，2 を満たす任意のモデル誤差に対し， ある $0 \leq \omega_{c}$ があり， $\omega>\omega_{c}$ で

$\operatorname{Re}[T(j \omega)]<0.5$

とする. $0 \leq \omega \leq \omega_{c}$ で, $T(j \omega)$ のベクトルが

(a) $H\left(\gamma, \bar{\theta}\left(\omega_{c}\right)\right)\left(\left|W_{I}\left(j \omega_{c}\right)\right| \leq \gamma \leq 1\right)$ の内側，あるいは

(b) $H(\gamma, \bar{\theta}(\omega))\left(\left|W_{I}(j \omega)\right| \leq \gamma \leq 1\right)$ の内側

にあれば，(31) 式の $M(s)$ を用いた(16) 式は安定である.

(証明) 仮定から， $\omega>\omega_{c}$ で(26)，(27)式を満たす。ま た, $0 \leq \omega \leq \omega_{c}$ で, $-1 / Q(j \omega)$ のべクトルは, $H(\gamma$, $\left.\bar{\theta}\left(\omega_{c}\right)\right)\left(\left|W_{I}\left(j \omega_{c}\right)\right| \leq \gamma \leq 1\right)$, あるいは, $H(\gamma, \bar{\theta}(\omega))\left(\left|W_{I}(j \omega)\right| \leq\right.$ $\gamma \leq 1)$ の外側にある. $T(j \omega)$ のベクトルが，それらの内側に あれば, $T(j \omega)$ のベクトルは, $-1 / Q(j \omega)$ のべクトルの延長 上にいくことはない. 定理 2 から制御系は安定である(証明 終).

制御対象が安定なとき，後で述べるように $|G(j \omega) P(j \omega)|$ $\leq 1, \angle G(j \omega) P(j \omega) \leq 0$ にすることができる.このとき, 上 記はつぎのように簡単化される。

〈定理 4〉仮定 $1 ， 2\left(\right.$ ただし $\left.\left|W_{I}(j \omega)\right|=0\right)$ を満たす任意の モデル誤差に対し，すべての $\omega \geq 0$ で $|G(j \omega) P(j \omega)| \leq 1$, $\angle G(j \omega) P(j \omega) \leq 0$ で, かつ, $\omega>2 /(\sqrt{3} L)$ で

$\operatorname{Re}[T(j \omega)]<0.5$

であれば，(31)式の $M(s)$ を用いた (16) 式は安定である.

(証明) $\omega_{c}=2 /(\sqrt{3} L)$ とおくと, $\omega>\omega_{c}$ で $\operatorname{Re}[T(j \omega)]$ $<0.5$ である。また，

$$
\bar{\theta}\left(\omega_{c}\right)=-\frac{2}{\sqrt{3}}+\frac{\pi}{3}>-\frac{\pi}{28}
$$

であるので, Fig. 5 から, $H\left(\gamma, \bar{\theta}\left(\omega_{c}\right)\right)(0 \leq \gamma \leq 1)$ は単位円外 にある。 $T(j \omega)$ のベクトルは単位円内にあるから； $0 \leq \omega \leq$ $\omega_{c}$ で $H\left(\gamma, \bar{\theta}\left(\omega_{c}\right)\right)$ の内側にある。したがって, 定理 3 から, 制御系は安定である(証明終).

\section{6. 制御器 $G_{c}(s)$ の設計}

定理 3 あるいは 4 のロバス卜安定条件，および，ステップ 目標, 外乱に対する定常偏差を 0 にするための $S(0)=0$ を満 たす制御器 $G_{c}(s)$ は, つぎのように設計できる.

ステップ 1 : 制御対象のモデル $G(s)$ を，不安定零点やむ だ時間を含まず，かつ，(30)式の右辺を満たすように選ぶ. $G(s)$ の相対次数を $n$ とする。もし, 制御対象が不安定零点 やむだ時間を含むときは，それらをモデル誝算 $1+\Delta(s)$ に含 める.

ステップ 2 : モデル $G(s)$ のステップ応答に対する, 制御 対象のステップ応答の遅れ時間 $L$ を求め, $M(s)$ を(31) 式と おく.

ステップ $3:$ 制御対象が安定のとき $\left|W_{I}(j \omega)\right|=0$ とし, つ ぎのステップへ. 制御対象が不安定のとき， $0 \leq \omega \leq \sqrt{2} / L$ で

$$
\left|W_{I}(j \omega) \leq\right| \frac{|G(j \omega)(1+\Delta(j \omega))|}{|G(j \omega)|}
$$

を満たす $\left|W_{I}(j \omega)\right|$ を求める.

ステップ $4: \tau_{i}>0(1 \leq i \leq 2)$ を適当に選ぶ. その $1 / 5 \sim 1 / 10$ の値を残りの $\tau_{i}>0(i=3, \cdots, n)$ とする.

$$
\begin{aligned}
\text { ステップ } 5: \\
P_{1}(s)=G^{-1}(s) F(s)
\end{aligned}
$$

とする. $F(s)$ は $P_{1}(s)$ をプロパーにするローパス・フィル 夕

$$
F(s)=\frac{1}{\prod_{i=1}^{n}\left(1+\tau_{i} s\right)}
$$

である。

ステップ 6 : 制御対象が安定のとき, $P_{2}(s)=1$ とし,つぎ のステップへ。制御対象が不安定のとき

$$
P_{2}(s)=\frac{1+c_{1} s+\cdots+c_{m} S}{(1+\tau s)^{m}}
$$

と㧈く、ただし， $m$ は $G(s)$ の不安定極数であり， $\tau>0$ は 任意の実数である. $c_{1}, \cdots, c_{m}$ を

$$
1-G(s) P_{1}(s) P_{2}(s) M(s)=1-P_{2}(s) F(s) M(s)
$$

が， $G(s)$ の不安定極と同じ点に零点をもつょうに決める。

$$
\text { ステップ7: }
$$$$
P(s)=P_{1}(s) P_{2}(s)
$$

とおく. $T(j \omega)=F(j \omega) P_{2}(j \omega) M(j \omega)$ のベクトル軌跡を描き, 制御対象が安定なときは， $\omega>2 /(\sqrt{3})$ で $\operatorname{Re}[T(j \omega)]<0.5$ を満たされるかどうか調べる、満たされれば，つぎのステッ プへ。満たされないときは, $\tau_{i}>0(i=3, \cdots, n)$ の值を小さく してステップ 5 亿. 制御対象が不安定のときは, $\omega>\omega_{c}$ で $\operatorname{Re}[T(j \omega)]<0.5$ を満たす $\omega_{c}$ があるかを調べる。なければ $\tau_{i}>0(i=3, \cdots, n)$ の值を小さくしてステップ 5 へ. $\omega_{c}$ があ れば, $0 \leq \omega \leq \omega_{c}$ で, $T(j \omega)$ のべクトルが $H(\gamma$, $\left.\bar{\theta}\left(\omega_{c}\right)\right)\left(\left|W_{I}\left(j \omega_{c}\right)\right| \leq \gamma \leq 1\right)$ の内側にあるかどうか調べる.内 側になければ $H(\gamma, \bar{\theta}(\omega))\left(\left|W_{I}(j \omega)\right| \leq \gamma \leq 1\right)$ の内側にあるか ぞうか調べる. 満たしていればつぎのステップへ。そうでな 
いときは， $\tau_{i}>0(i=1,2)$ を少し大きくする．その $1 / 5 \sim 1 / 10$ の值を残りの $\tau_{i}>0(i=3, \cdots, n)$ としステップ 5 へ.

ステップ $8: P(s)$ を(11)式に代入し，その最小実現を制 御器 $G_{c}(s)$ とする.

上記のステップ 4 で， $\tau_{i}>0(1 \leq i \leq 2)$ を適当に選び，その $1 / 2 \sim 1 / 10$ の值を残りの $\tau_{i}>0(i=3, \cdots, n)$ にしている.これ は, $\omega>\omega_{c}$ で $\operatorname{Re}[T(j \omega)]<0.5$ にするためである.

制御対象が安定のとき，モデル誤差に依存せず； $\tau_{i}>0$ $(1 \leq i \leq 2)$ を任意に選ぶことができるエラー・フリー設計に なっている8),9)。このとき感度, 相補感度は

$$
\begin{aligned}
& S(s)=1-\frac{1}{\prod_{i=1}^{n}\left(1+\tau_{i} s\right)} M(s) \\
& T(s)=\frac{1}{\prod_{i=1}^{n}\left(1+\tau_{i} s\right)} M(s)
\end{aligned}
$$

である，相補感度は，任意の高い周波数まで $|T(j \omega)| \approx 1$ に できる。感度は, $M(s)$ で決まる。

制御対象が不安定なとき, 感度, 相補感度は, それぞれ

$$
\begin{gathered}
S(s)=1-\frac{1}{\prod_{i=1}^{n}\left(1+\tau_{i} s\right)} \frac{1+c_{1} s+\cdots+c_{m} s^{m}}{(1+\tau s)^{m}} M(s) \\
T(s)=\frac{1}{\prod_{i=1}^{n}\left(1+\tau_{i} s\right)} \frac{1+c_{1} s+\cdots+c_{m} s^{m}}{(1+\tau s)^{m}} M(s)
\end{gathered}
$$

となる. 上式の, $\tau_{i}>0(i=1,2)$ の值は, $T(j \omega)$ のべクトル が $0 \leq \omega \leq \omega_{c}$ で $H\left(\gamma, \bar{\theta}\left(\omega_{c}\right)\right)\left(W_{I}\left(\omega_{c}\right) \leq \gamma \leq 1\right)$ あるいは $H(\gamma$, $\bar{\theta}(\omega))\left(\left|W_{I}(j \omega)\right| \leq \gamma \leq 1\right)$ の内側にある範囲で任意に選ぶこと ができる。これより，相補感度のゲイン $|T(j \omega)|$ を高い周波 数まで 1 の近くに止めておくことができる．感度の低減化 は，自動的にモデル誤差に依存する $M(s)$ で決まる．感度と 相補感度のトレードオフがなく，これが， $H^{\infty}$ 制御との大き な違いである。

\section{7. 数 值 例}

\section{1 安定な対象}

制御対象 $G(s)(1+\Delta(s))$ の $G(s), 1+\Delta(s)$ を

$$
G(s)=\frac{2}{s+1}, 1+\Delta(s)=\frac{1}{(1+0.4 s)(1+0.2 s)(1+0.1 s)}
$$

とする． 6 節の設計はつぎのようになる．モデル誤差のゲイ ンが仮定 1 を満たす $G(s)$ となっている．仮定 2 の $L$ を見積 もる. Fig. 6 に示すように. $G(s) e^{-s L}$ のステップ応答(鎖 線)が制御対象 $G(s)(1+\Delta(s))$ のステップ応答(実線)に重な るような $L$ を求め $L=0.7$ とする.

確認のため $1+\Delta(j \omega)$ と $e^{-j \omega L}$ の位相をみると Fig. 7 とな る. $L=0.7$ で仮定 1 が満たされていることがわかる. 位相補償器を

$$
M(s)=\frac{1-0.35 s}{1+0.35 s}
$$

とする. 設計アルゴリズムのステップ 3 で $\tau=0.05$ に選ぶ と

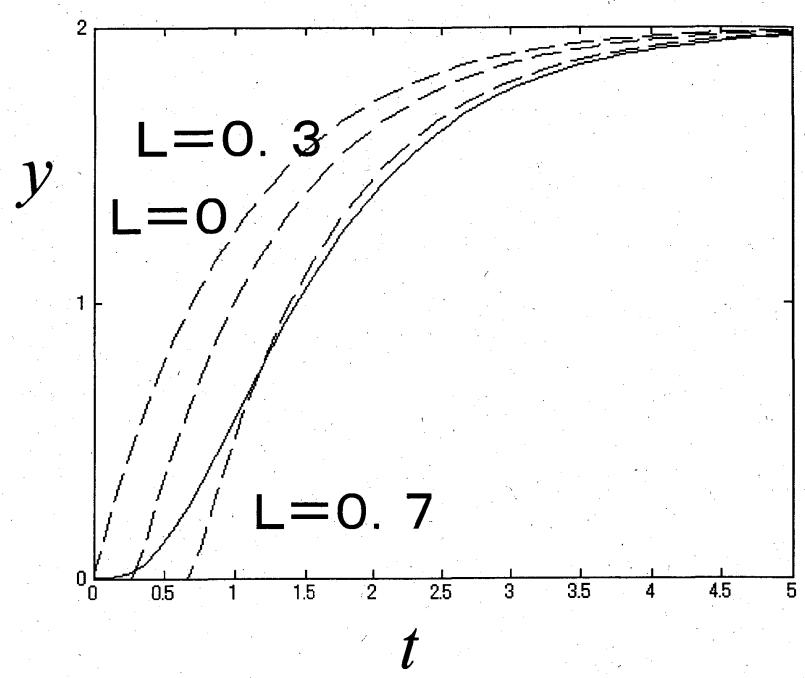

Fig. 6 Detection of $L$ from step responses

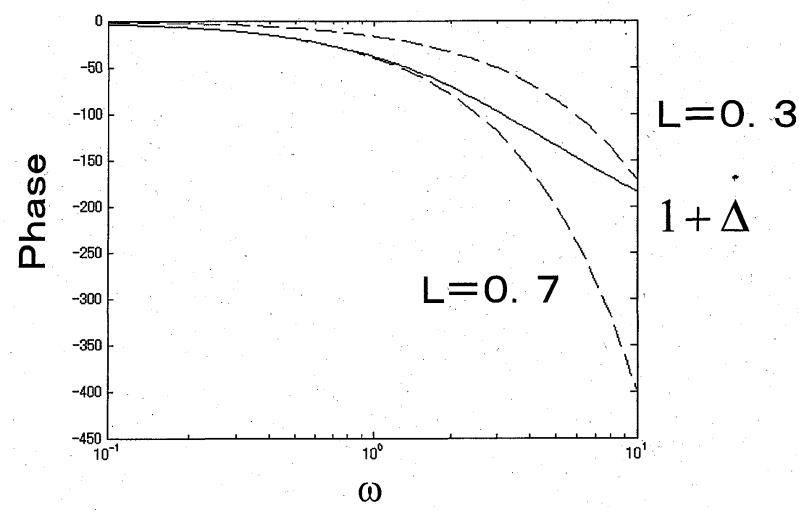

Fig. 7 Phase diagram of model error and delay

$$
\begin{aligned}
& P(s)=\frac{s+1}{2} \frac{1}{1+0.05 s} \\
& G_{c}(s)=\frac{10 s^{2}+38.6 s+28.6}{s(s+42.9)}
\end{aligned}
$$

が得られる。

比較のために $H^{\infty}$ 制御ではつぎのようになる。モデル誤差 の評価は (8) 式から行なう。低周波では (8) 式左辺を, 高周 波では右辺を抑える重み関数 $W_{T}(s)$ と対応する感度重みを

$$
W_{T}(s)=\frac{1+1.2 s}{2}, W_{s}(s)=\frac{1}{s+0.01}
$$

とする，混合感度仕様

$$
\left\|\begin{array}{l}
W_{s}(s) S(s) \\
W_{T}(s) T(s)
\end{array}\right\|<1
$$

を満たす $H^{\infty}$ 制御器は

$$
G_{c}(s)=\frac{3.23(s+1)}{(s+0.01)(s+4.98)}
$$

で与えられる11.

提案方法と $H^{\infty}$ 制御系の感度，相補感度を Fig. 8 亿示す. 感度は，ほぼ等しい值である。これは, 提案方法は $M(j \omega)$ で， $H^{\infty}$ 制御はモデル誤差の見積もり $W_{T}(s)$ に依存する $W_{s}(s)$ によって決まり，いずれもモデル誤差に依存するため と考えられる。相補感度は，提案方法が高周波まで $0 \mathrm{~dB}$ 帯 


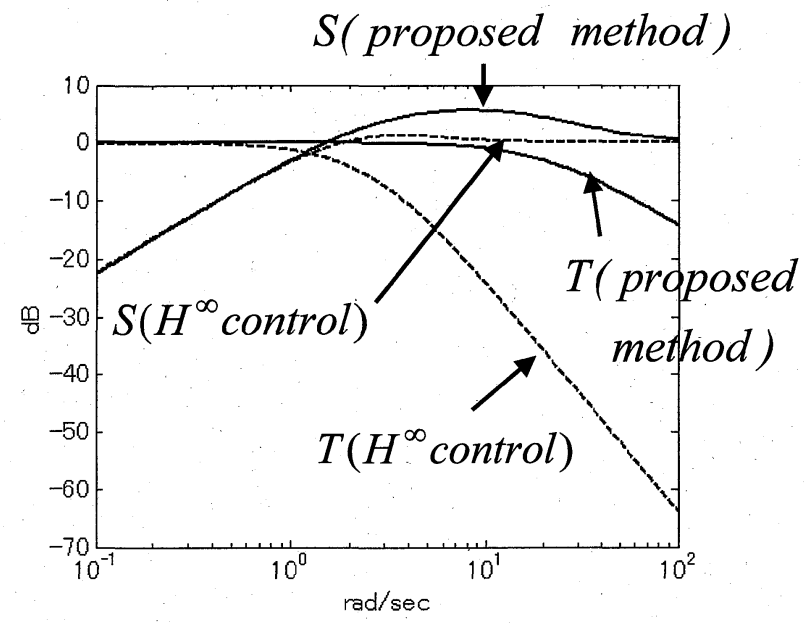

Fig. 8 Sensitivity and complementary one

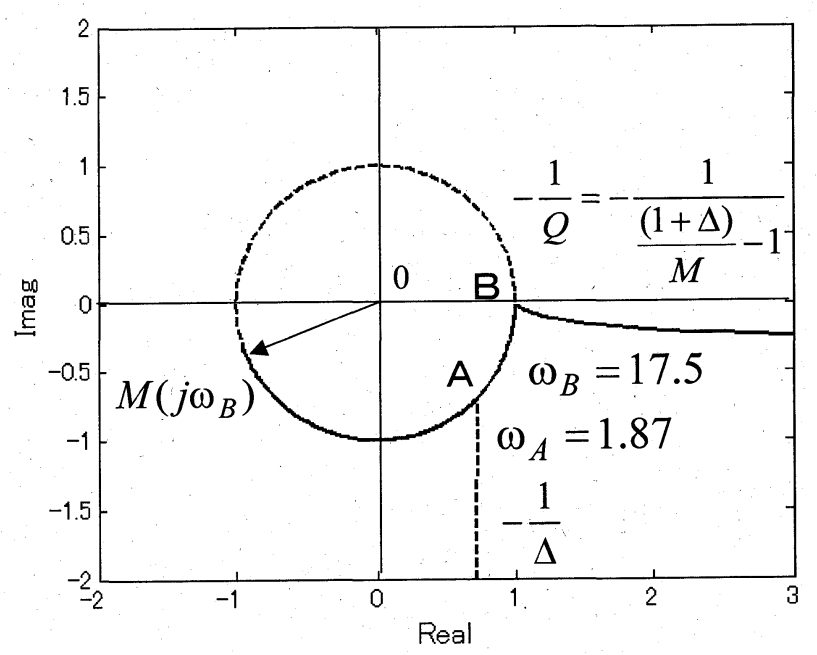

Fig. 9 Comparison of $1 / \Delta$ and $-1 / Q$

\section{域が延びている.}

これは，定理 1 の Fig. 4 をもとに説明できる．従来の口 バスト制御は， $M(s)=1, Q(s)=\Delta(s)$ に相当する. Fig. 9 で, $-1 / \Delta(j \omega)$ のベクトル軌跡が単位円に達する角周波数 は, $\omega_{A}=1.87(\mathrm{rad} / \mathrm{s})$ である。この角周波数までに，相補 感度 $T(j \omega)$ を, A 点から時計方向に回転させなければなら ない.これによって, $H^{\infty}$ 制御の相補感度の $0 \mathrm{~dB}$ 周波数帯 域が制限される。一方，提案方法では，モデル誤差の位相が 補償されているので，単位円に達する角周波数は， $\omega_{B}=$ $17.5(\mathrm{rad} / \mathrm{s})$ と高くなる。さらに，(14)式から，T(s)は $M(s)$ を含み, $M\left(j \omega_{B}\right)$ のべクトルは B 点より大きく時計方 向に回転しているので，高い周波数まで $G(j \omega) P(j \omega) \approx 1$ に しても安定を保つことができるのである，これが位相補償の 効果である。

ステップ応答を Fig. 10 に示す. $H^{\infty}$ 制御では振動的な応 答である．提案方法で立ち上がり，オーバーシュート，整定 時間ともに短い良好な応答である。この違いは, 従来方法の $T(j \omega) \Delta(j \omega)$ と本方法の $T(j \omega) Q(j \omega)$ のベクトル軌跡を比較 した Fig. 11 からわかる. 従来方法の $T(j \omega) \Delta(j \omega)$ のベクト

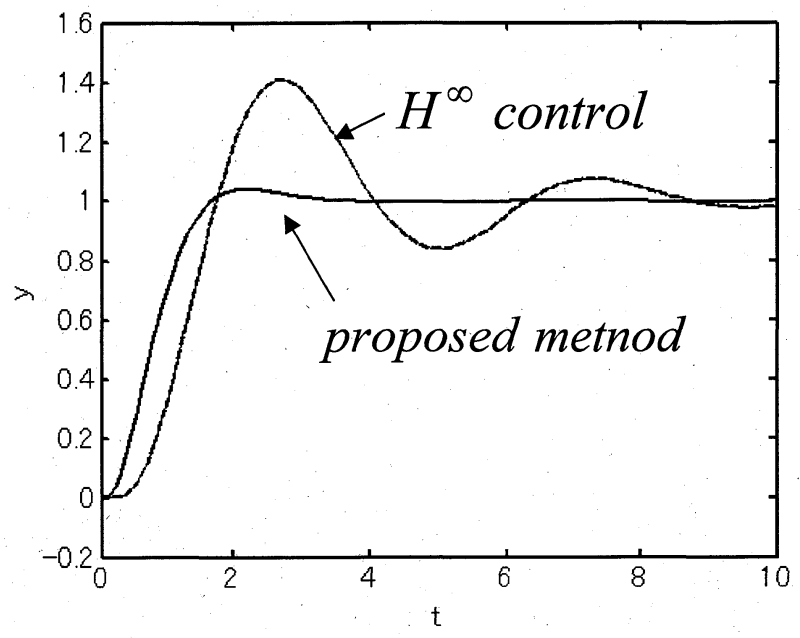

Fig. 10 Step responses

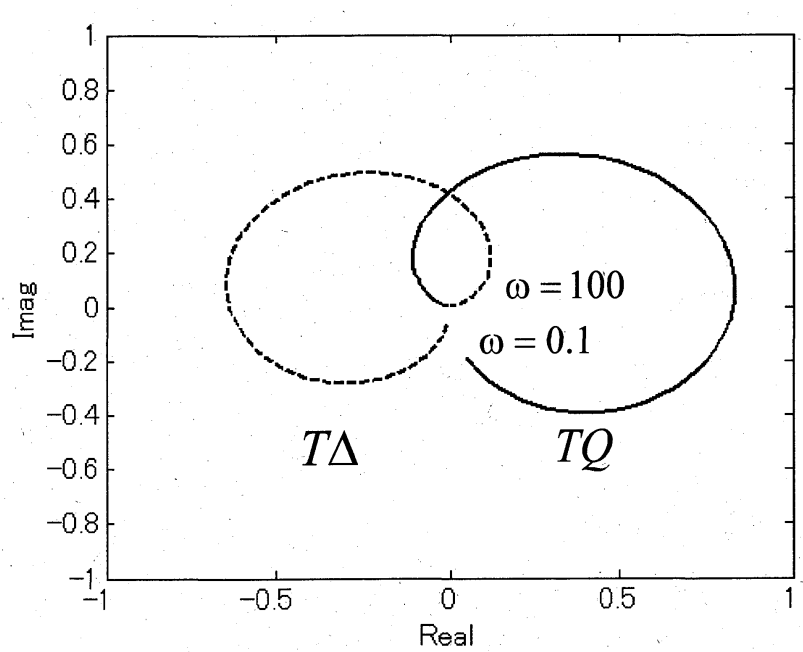

Fig. 11 Comparison of $T(j \omega) \Delta(\omega)$ and $T(j \omega) Q(j \omega)$.

ル軌跡は, 時計方向に回転し, 点 $(-1,0)$ に近いところを通 るため, ステップ応答が振動すると考えられる。一方，提案 方法の $T(j \omega) Q(j \omega)$ のベクトル軌跡は，反時計方向に回転 し, 点 $(-1,0)$ から離れたところを通る。これによって, 良 好なステップ応答になっていると考えられる。なお， $T(j \omega) Q(j \omega)$ のべクトル軌跡が反時計方向に回転するのは,

$T(j \omega) Q(j \omega)=G(j \omega) P(j \omega)\{1+\Delta(j \omega)-M(j \omega)\}$

で, ベクトル $1+\Delta(j \omega)$ と $M(j \omega)$ の位置関係で, $\{1+\Delta(j \omega)$ $-M(j \omega)\}$ が Fig. 3 に示されるように位相進みベクトルとな るからである.これも位相補償の効果である。

\section{2 不安定系}

不安定制御対象 $G(s)(1+\Delta(s))$ を考える，ただし，

$$
G(s)=\frac{1}{s-1}, 1+\Delta(s)=\frac{1}{(1+0.1 s)^{3}}
$$

とする. $G(s) e^{-s L}$ と制御対象 $G(s)(1+\Delta(s))$ のステップ応 答の立ち上がり部分が合うようにむだ時間 $L$ を求めると $L$ $=0.3$ であり, 位相補償器を

$$
M(s)=\frac{1-0.15 s}{1+0.15 s}
$$




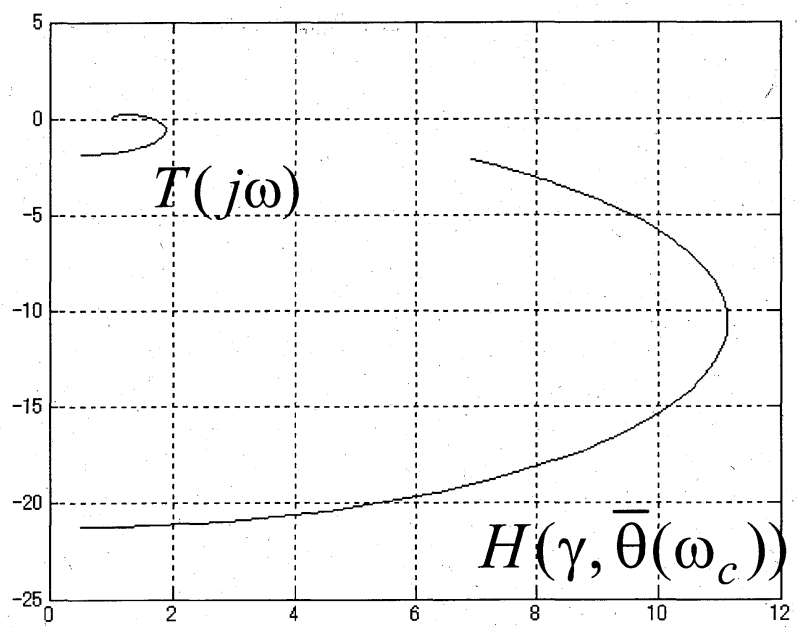

Fig. 12 Stability check

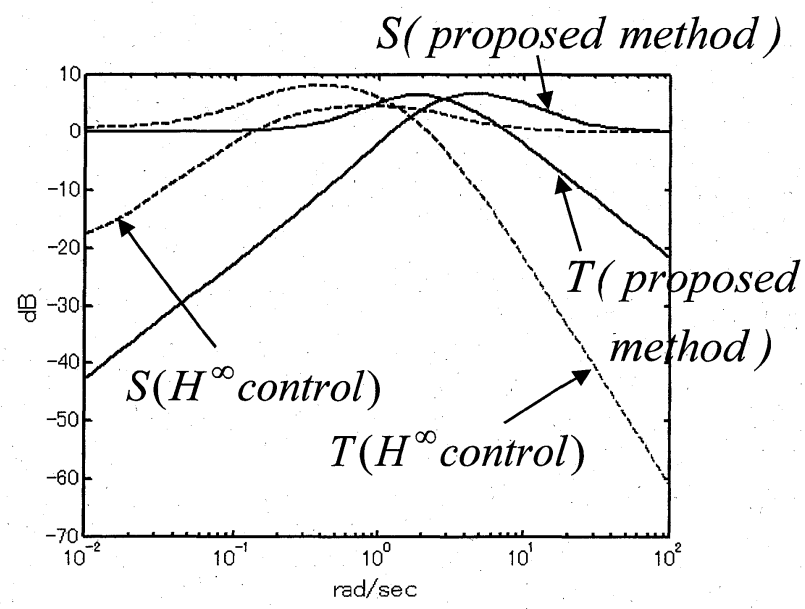

Fig. 13 Comparison of $H^{\infty}$ control and phase-compensated robust control

とする.

つぎに $0 \leq \omega \leq \sqrt{2} / L て ゙ ，(30)$ 式を満たす $W_{I}(s)$ は

$$
W_{I}(s)=\frac{1}{1+0.2 s} .
$$

である: $\tau=0.5$ に選ぶと

$$
P_{1}(s)=\frac{s-1}{1+0.5 s}, P_{2}(s)=\frac{1+2.04 s}{1+0.5 s}
$$

が得られる.このとき， $\omega>\omega_{c}=2.85$ で $\operatorname{Re}[T(j \omega)]<0.5$ で あり，

$$
\left|W_{I}\left(j \omega_{c}\right)\right|=0.868
$$

となる. $0 \leq \omega \leq \omega_{c}$ で, $T(j \omega)$ のベクトルは, Fig. 12 に示 されるように, $H\left(\gamma, \bar{\theta}\left(\omega_{c}\right)\right)\left(\left|W_{I}\left(j \omega_{c}\right)\right| \leq \gamma \leq 1\right)$ の内側にあ る. 定理 3 からフィードバック系は安定である.

これより制御器は次式で与えられる。

$$
G_{c}(s)=\frac{8.18(s+0.489)(s+6.67)}{s(s+19.8)}
$$

$H^{\infty}$ 制御では，モデル誤差に対し $(7)$ 式を満たす重み関 数, 感度仕椂に対する重み関数を, それぞれ

$$
W_{T}(s)=\frac{1+s}{3}, W_{s}(s)=\frac{0.1}{s+0.01}
$$

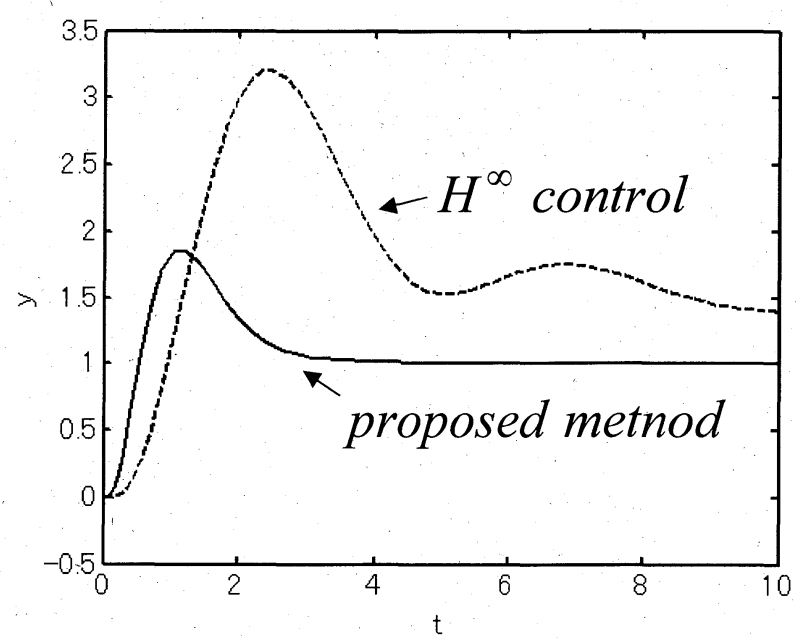

Fig. 14 step responses

とする。このとき混合感度仕様を満たす解が存在し制御器は

$$
G_{c}(s)=\frac{8.5(s+0.068)}{(s+0.01)(s+5.0)}
$$

で与えられる. 感度と相補感度のボード線図を Fig. 13 に, ステップ応答をFig. 14 に示す. 7.1 の例で述べたと同様な 仕組みで，提案方法がはるかに良い応答になっていることが わかる。

\section{8. おわりに}

IMP をとに，位相補償を考慮した新しいロバスト制御 法を提案した。そのキーポイントは 3 つある.1つは，モデ ル誤差を $\Delta(s)$ でなく, $1+\Delta(s)$ で見積もることであり，そ のため位相とゲインをより正確に, 簡単に見積もることがで きる. $2 つ$ 目は, IMP の構造を用いて位相補償することで ある。これにより安定範囲の拡大や制御特性が改善できる。 3つ目は，包・荒木の方法を応用し，位相を考慮した安定の 十分条件を与えたことである。これらにより，従来より優れ た特性をもつロバスト制御系を簡単に設計することができ る.

\section{参 考 文 献}

1) 美多 勉: $H^{\infty}$ 制御, 昭晃堂 (1994)

2) M. Morri and E. Zafiriou: Robust Process Control, Prentice Hall (1989)

3）渡部慶二：IMC の感度とロバスト安定性, 第 21 回制御理論シ ンポジウム, 203/206 (1992)

4) Z. B. Shu, G. Izuta, K. Watanabe and K. Yamada: Unification of modeling and control for desired control performances, IEEE CDC, 893/894 '(1996)

5）山田 功：位相を考慮したロバスト安定性と低感度化，シス テム制御情報学会論文誌, 11-7, 375/383（1998）

6）山田 功：位相を考慮したロバス卜安定化の拡張一位相次数 が不確かなシステムに対する拡張，システム制御情報学会論 文誌, 12-9, 522/5303 (1999)

7）包・荒木：むだ時間を含むプラントに対する状態予測制御系 のロバスト安定性, システムと制御, 32-1, 58/65（1988）

8) K. Watanabe and E, Muramatsu: Erro-Independent Stabilization of Internal Model Control, SICE Annual Conference, 312/317 (2003) 
9) K. Watanabe, E. Muramatsu, Y. Ariga and S. Endo: Error-Free Robust Stabilization, SICE Annual Conference, $361 / 366$ (2004)

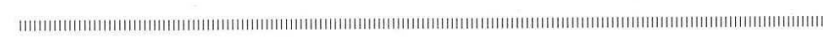

$$
\text { [著 者 紹介] }
$$

王

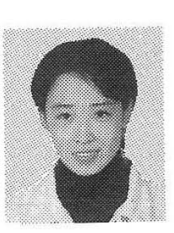

\section{思 (学生会員)}

2002 年中国東北大学自動化学科卒業。2005 年 山形大学大学院工学研究科電子情報工学専攻修 了. 同年同大学大学院理工学研究科システム情報 工学専攻博士後期課程に入学し, 現在に至る。口 バスト内部モデル制御, 非干渉化制御の研究に従 事.

\section{渡 部 慶 二（正会員）}

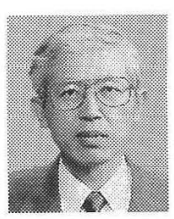

1966 年山形大学工学部電気工学科卒業. 同年 山形大学助手, 78 年講師, 85 年助教授, 89 年教 授, 現在, 同大学応用生命システム工学科教授, 理化学研究所 BMC 研究センター客員研究員. む だ時間系の制御，内部モデル制御，ロバスト制御 等の研究に従事. 工学博士. システム制御情報学 会, 日本ロボット学会の会員.

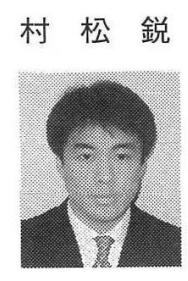

一 (正会員)

1991 年名古屋大学大学院研究科情報工学専攻 修士課程修了。同年住友金属工業(株) に入社，95 年神戸商船大商船学部助手, 99 年大阪府立大学 工学部講師, 2002 年山形大学工学部助教授とな り現在に至る。システム制御理論の研究に従事, 博士(工学)。システム制御情報学会, IEEE など の会員.

\section{有 我 祐 一 (正会員)}

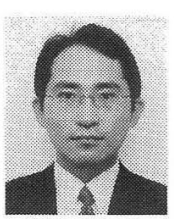

2001 年千葉大学大学院自然科学研究科後期課 程修了。同年石川島播磨重工業(株) (基盤技術研 究所) 入社. 2003 年山形大学工学部助手, 現在に 至る. 主として磁気軸受, 振動制御, 步行ロボッ 卜などの研究に従事. 2001 年度日本 AEM 学会 奨励賞受賞, 博士 (工学). 日本機械学会, 日本 $\mathrm{AEM}$ 学会, 日本ロボット学会の会員.

遠 藤茂

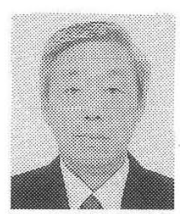

1959 年山形県立長井工業高等学校電子科卒業, 同年山形大学工学部勤務, 現在に至る。レーザー の基礎・計測応用，メカニカルシステムの計測制 御に関する研究㧍よび補助等に従事。 